\title{
PERLINDUNGAN HUKUM BAGI PEKERJA AKIBAT PEMUTUSAN HUBUNGAN KERJA PADA MASA PANDEMI COVID-19
}

\author{
Eggy Septyadi Silaban, Desak Gede Dwi Arini, Luh Putu Suryani \\ Fakultas Hukum, Universitas Warmadewa, Denpasar-Bali, Indonesia \\ eggymaster12345678910@gmail.com, arinidesak1966@gmail.com putusuryani099@gmail.com
}

\begin{abstract}
Abstrak
Saat ini dibelahan bumi manapun sedang menghadapi suatu virus yang disebut dengan Covid-19. Sejak munculnya kasus ini, segala akses menjadi terhambat khususnya dibidang ekonomi. Meningkatnya pengangguran menjadi salah satu permasalahan saat ini, untuk itu diperlukannya suatu perlindungan hukum untuk menjamin kehidupan bagi para para pekerja pada masa pandemi ini. Tujuan penelitian ini untuk menganalisa pengaturan pemutusan hubungan kerja bagi pekerja akibat pandemi covid-19 serta perlindungan hukum terhadap pekerja karena pemutusan hubungan kerja akibat pandemi covid-19. Penelitian ini merupakan jenis penulisan hukum normatif dengan pendekatan konseptual serta perundang-undangan. Sumber data yang digunakan berupa sumber data sekunder dan primer. Teknik pengumpulan data dengan mengklasifikasikan bahan hukum primer dengan bahan hukum sekunder sebagai penunjang penelitian. Adapun analisis bahan hukum diperoleh dengan analisis kualitatif. Hasil penelitian menunjukkan bahwa Pemutusan Hubungan Kerja berdampak buruk bagi para perkerja karena kehilangan pekerjaan sehingga berdampak juga pada meningkatnya tingkat kemiskinan masyarakat Indonesia. Karena munculnya aturan PSBB dari pemerintah tentunya membuat ruang gerak untuk bekerja semakin sempit dan PHK semakin marak terjadi, maka dari itu pengaturan Undang-undang No. 13 Tahun 2003 Tentang Ketenagakerjaan dan juga peran pemerintah sangatlah penting untuk mengatasi terjadinya PHK yang tidak sesuai dengan peraturan Perundang-Undangan. Adapun perlindungan hukumnya dibagi menjadi 2 hal yakni perlindungan hukum Preventif dan perlindungan hukum Represif.
\end{abstract}

Kata Kunci: Covid-19, Perlindungan Hukum, Pemutusan Hubungan Kerja (PHK).

\begin{abstract}
Currently, any part of the world is facing a virus called Covid-19. Since the emergence of this case, all access has been hampered, especially in the economic field. Increasing unemployment is one of the current problems, for that we need a legal protection to ensure life for workers during this pandemic. The purpose of this study to analyze. Arrangements for termination of employment for workers due to the COVID-19 pandemic as well as legal protection for workers due to termination of employment due to the COVID-19 pandemic. This research is a type of normative legal writing with a conceptual approach and legislation. Sources of data used in the form of secondary and primary data sources. Data collection techniques by classifying primary legal materials with secondary legal materials as research support. The analysis of legal materials obtained by qualitative analysis. The results of the study indicate that Termination of Employment has a negative impact on workers because they lose their jobs so that it also has an impact on increasing the poverty level of the Indonesian people. Because the emergence of PSBB regulations from the government of course makes the space for work narrower and layoffs are increasingly prevalent, therefore the regulation of Law no. 13 of 2003 concerning Manpower and also the role of the government is very important to overcome the occurrence of layoffs that are not in accordance with the laws and regulations. The legal protection is divided into 2 things, namely preventive legal protection and repressive legal protection.
\end{abstract}

Keywords: Covid-19, Legal Protection, Termination of Employment.

\section{PENDahuluan}

Pada dasarnya sebuah pekerjaan wajib hukumnya untuk memiliki suatu hubungan kerjasama antara pekerja dan pemberi kerja untuk bisa meningkatkan kualitas dan juga mutu para pekerja yang nantinya akan berpengaruh ke kualitas perusahaan dan tentunya bisa membuat keuntungan yang besar bagi perusahaan dan pekerja itu sendiri. Pekerja adalah roda penggerak perusahaan yang 
menjadi tulang punggung yang berperan penting dalam alur usahanya. Oleh karenanya untuk dapat meningkatkan kualitas pekerja dibutuhkan suatu perlindungan hukum untuk pekerayang sesuai dengan hak serta kewajiban masing-masing pihak (Khakim, 2003).

Permasalahan Pandemi COVID-19 yang semakin meningkat di negeri kita membuat pemerintah memiliki pemikiran untuk melaksanakan Pembatasan Sosial Berskala Besar (PSBB) yang mana telah diatur pada Peraturan Pemerintah Nomor 21 Tahun 2020 tentang penekanan dan, pembatasan aktivitas pekerja yang memiliki tujuan untuk bisa memutuskan dengan cara mencegah pergerakan masyarakat, memutus rantai penyebaran virus COVID-19. Karena ini menimbulkan terjadinya suatu pemberhentian sementara untuk menjalankan suatu proses kerja pada suatu perusahaan, yang mana tentunya akan memiliki dampak bagi para pekerja/buruh, hal ini menyebabkan terjadinya peningkatan jumlah pengurangan di Indonesia dengan banyaknya perusahaan yang melakukan pemutusan hubungan kerja secara sepihak. Hal tersebut merujuk pada Pasal 163 Ayat (1) Undang-undang Nomor 13 Tahun 2003 tentang Ketenagakerjaan. Seorang pekerja/buruh yang menerima dampak PHK memiliki kerugian yang besar terlebih bagi pekerja yang telah mengabdikan diri sangat lama untuk perusahaan. Dalam konteks PHK ini pemerintah sebaiknya mengeluarkan suatu aturan baru untuk bisa melindungi para pekerja dari PHK sepihak yang merugikan Pekerja.

International Labour Organization (ILO) mengatakan bahwa sudah ada sekitar 25 (dua puluh lima) juta pekerja terkena PHK akibat Pandemi. menurut Menteri Keuangan Ibu Ida Fauziah mengirangira sudah ada sekitar 2 (dua) juta lebih pekerja yang ter-PHK akibat hal ini. Pada tanggal 24 April 2020 LIPI (pusat penelitian) bersamaan dengan (LD-UI) Lembaga demograsi Univ. Indonesia telah melakukan survey secara online mengenai dampak Covid-19 pada pekerja yakni terdapat total respondennya 112 pekerja. Dan pada survey online diperkirakan di Provinsi Bali sejumlah 443 (empat ratus empat puluh tiga) pekerja terdampah pandemic. Selain itu di tanggal 1 (satu) Mei 2020 data dari KEMENAKER (kementrian Ketenagakerjaan) meneliti bahwa pada sektor informal 375.165 (tiga ratus tujuh puluh lima ribu seratus enam puluh lima) orang ter-PHK akibat Pandemi, sedangkan di sektor formal yang terdapat sebesar 1.032.960 pekerja (Ngadi et al., 2008).

Terdapat penelitian terdahulu yang relevan dengan penelitian ini. Pada dasarnya negara wajib memberikan perlindungan hukum bagi setiap warga negaranya, dengan memberikan kebijakankebijakan yang dapat membantu masyarakat untuk mendongkrak perekonomian mereka. Serta wajibnya negara untuk hadir ditengah-tengah perselisihan industrial dan mengupayakan penyelesaian secara musyawarah sebagai jalan keluar bagi pengusaha dan pekerja/buruh dalam mencegah PHK akibat pandemi Covid-19 namun apabila PHK tidak dapat dihindarkan maka pengusaha wajib memberikan pesangon uang penghargaan masa kerja, dan uang penggantian hak sesuai yang diatur oleh peraturan perundang-undangan serta tidak lupa bagi pekerja dengan status tidak tetap wajib mendapat uang kompensasi (Pamungkas \& Irawan, 2021). Adapun penelitian dari Hatane et al., (2021) bahwa pengimplementasian dari perlindungan hukum bagi pekerja yang di PHK yaitu sesuai dengan surat edaran yang dikeluarkan oleh pemerintah terkait hak-hak yang dipenuhi atas kesepakatan bersama walaupun dalam konteksnya ada juga hak pekerja yang tidak sepenuhnya terpenuhi sesuai dengan ketentuan peraturan perundangundangan, hingga pada diterbitkannya program kartu prakerja, program padat karya tunai serta jaring pengaman sosial. Maksud dan tujuan perlindungan bagi para pekerja adalah agar pekerja dapat dilindungi dari perlakuan pemerasan/ketidakadilan oleh pihak pengusaha. Pemerintah sangat menaruh perhatian terhadap masalah perlindungan pekerja/buruh karena pada umumnya posisi pekerja masih lemah, sehingga perlindungan kerja dan keselamatan kerja akan dapat mewujudkan terpeliharanya kesejahteraan, kesehatan, kedisplinan pekerja yang berada di bawah pimpinan pengusaha (Wibowoa \& Sudiro, 2021).

Berdasarkan uraian diatas, maka tujuan penelitian ini untuk menganalisa pengaturan pemutusan hubungan kerja bagi pekerja akibat pandemi covid-19 serta perlindungan hukum terhadap pekerja karena pemutusan hubungan kerja akibat pandemi covid-19.

\section{METODE PENELITIAN}

Penelitian ini merupakan penelitian hukum normatif, yang dimana meletakkan hukum sebagai suatu sistem norma yang diberlakukan. Tipe ini diterapkan untuk penerapan kaidah norma yang berlaku didalam hukum positif Indonesia. Penelitian ini dibuat dengan menganalisis hukum yang sifatnya formal. Adapun sumber bahan hukum primer berupa Undang-undang, serta juga seluruh peraturan 
secara hirarki, dan sumber bahan hukum primer yang berupa buku-buku yang memuat norma atau konsep teoritis dan juga pendapat dari para sarjana. Pendekatan masalah yang digunakan yakni pendekatan konseptual serta perundang-undangan, dimana pendekatan konseptual yakni seperti pendapat para sarjana secara teoritis, sedangkan pendekatan perundang-undangan adalah aturan tertulis yang dibuat oleh pejabat yang berwenang, dibentuk secara umum serta di sahkan oleh Negara (Marzuki, 2008). Analisis bahan hukum yang digunakan dalam penelitian ini adalah deskriptif kualitatif.

\section{HASIL DAN PEMBAHASAN}

\section{Pengaturan Pemutusan Hubungan Kerja Bagi Pekerja Akibat Pandemi Covid-19}

Terjadinya pemutusan hubungan kerja kepada rekan-rekan pekerja akan memiliki dampak yang buruk bagi pekerja, karena pekerja akan kehilangan pekerjaannya dan pengangguran di Indonesia Pun tentunya akan mengalami peningkatan. Hal ini menyebabkan terjadinya suatu ketidakseimbangan hidup bagi pekerja untuk dapat memenuhi kebutuhan hidup dirinya dan juga keluarganya (Ridwan, 2014). Hubungan kerja adalah hubungan dimana kedua belah pihak menjalin suatu kerjasama yakni antara para pekerja dengan perusahaan pada suatu perjanjian kerja dan peraturan kerja yang sudah diketahui beserta disepakati bersama-sama, baik pihak pekerja dan juga perusahaan kedua-duanya memiliki hak yang sama bersifat mutlak dan terikat satu sama lain dalam suatu perjanjian kerja tersebut, sehingga perusahaan memiliki hak yang kuat untuk menugaskan pekerjanya untuk bisa bekerja sesuai dengan kriteria perusahaan dan bisa memperoleh suatu keuntungan untuk perusahaan itu sendiri yang nantinya akan berpengaruh kepada penghasilan para pekerja yang menggerakkan roda perusahaan (Kartasapoetra et al., 1994).

Putusnya suatu hubungan kerja bisa saja terjadi secara otomatis pada kurun waktu yang telah ditentukan oleh para pihak baik pekerja maupun pihak perusahaan. Pemutusan hubungan kerja menurut Pasal 1 Ayat 25 Nomor 13 Tahun 2003 menyatakan bahwa berakhirnya suatu hubungan pekerjaan karena sesuatu hal yang mendesak (force majeure) yang menyebabkan putusnya hak dan juga kewajiban dari pekerja dan perusahaan (Uwiyono, 2014). Namun tertuang juga dalam Pasal 1 Ayat 23 Undang-Undang Nomor 13 Tahun 2003. Dengan demikian pemutusan hubungan kerja ialah segala jenis bentuk pengakhiran/pemutusan hubungan kerja antara para penerima pekerjaan dengan pengusaha atau pemberi kerja yang disebabkan karena terjadinya suatu keadaan tertentu yang mendesak. Lain halnya dengan pemutusan hubungan kerja yang dilakukan oleh perusahaan disebabkan oleh waktu yang telah ditetapkan pada suatu perjanjian telah berakhir karena menimbulkan permasalahan antara pekerja dan juga perusahaan, berbeda pula dengan PHK yang terjadi dikarenakan oleh terdapatnya suatu perselisihan yang akibatnya dari suatu keadaan yang mendesak (force majeure), dimana sebab ini tentunya akan menimbulkan dampak yang signifikan antara kedua pihak, khususnya pekerja itu sendiri yang notabenenya dari orang yang kedudukan perekonomianya sangatlah lemah (Soepomo, 2016).

Pengaturan pemutusan hubungan kerja diatur dalam beberapa alasan tertentu yakni

1. Pemutusan Hubungan kerja karena majikan Pemutusan hubungan kerja oleh majikan ini biasanya terjadi dikarenakan oleh pekerja itu sendiri yang melakukan suatu kesalahan atau pelanggaran hukum yang berat dan tidak bias dimaafkan oleh majikan/ pemberi kerja, hal ini telah diatur dalam Pasal 158 Ayat 1 Undang-Undang Nomor 13 Tahun 2003.

2. Pemutusan hubungan kerja oleh pihak pekerja hal ini biasanya karena pekerja melakukan pengunduran diri tanpa menyangkut pautkan pemberi kerja dan memang inisiatifnya untuk berhenti bekerja. Dalam hal ini tentunya pekerja harus memenuhi syarat sebagaimana yang tertulis dalam Pasal 162 Ayat 3 Undang-Undang Nomor 13 Tahun 2003.

3. Pemutusan hubungan kerja demi hukum Pemutusan hubungan kerja demi hukum adalah pemutusan hubungan kerja dengan sendirinya, sehubung dengan kontrak kerja atau lebih tepatnya jangka waktu perjanjian yang terjalin antara pekerja dan pemberi kerja/perusahaan yang diatur dalam Pasal 61 Ayat 1 Undang-Undang Nomor 13 Tahun 2003 (Asikin, 2010).

4. Pemutusan hubungan kerja karena putusan pengadilan Pemutusan hubungan kerja karena putusan pengadilan adalah jenis pemutusan hubungan kerja yang bisa juga terjadi jika para pekerja melakukan pelanggaran dari ketentuan yang telah diatur dalam suatu perjanjian kerja, perjanjian kerja bersama maupun peraturan perusahaan, lalu dimana pekerja yang melakukan pelanggaran telah dilakukan suatu pembinaan dengan adanya pemberian surat peringatan pertama, kedua, 
hingga ketiga dimana jangka waktu pemberian sp adalah masing-masing 6 (enam) bulan, namun saat berjalannya pekerja tersebut tidak dapat memperlihatkan suatu itikad baik atau tindakan yang lebih baik dari yang dilanggarnya serta tidak memiliki perubahan dalam kinerja pada perusahaan yang akhirnya dapat mengganggu keberlangsungan kerja. Ketentuan tersebut diatur dalam Pasal 154 Undang-Undang Nomor 13 Tahun 2004.

Pasal 164 ayat (1) UU Ketenagakerjaan pada dasarnya memberikan kebebasan kepada pengusaha untuk melakukan PHK kepada para pekerjanya. Namun UU Ketenagakerjaan tidak secara spesifik atau mendasar mengatur tentang kondisi apa-apa saja yang dimasukkan pada kategori force majeure dalam bidang ketenagakerjaan. Adapun beberapa Putusan Mahkamah Agung (MA) yang memiliki kekuatan hukum tetap dan bisa dijadikan sebagai rujukan dikarenakan perusahaan telah memutus mengenai PHK karena alasan tertentu yakni force majeure. Yakni Putusan MA No.156 PK/Pdt.Sus/2011 tanggal 29 Desember 2011, Putusan MA No. 350 K/Pdt.Sus/2012 tanggal 8 Agustus 2012, dan Putusan MA No. 795 K/Pdt.Sus- PHI/2019 tanggal 1 Oktober 2019.

\section{Perlindungan Hukum Terhadap Pekerja karena Pemutusan Hubungan Kerja Akibat Pandemi Covid-19}

Tercantum pada bunyi KUH Perdata Pasal 1244 dan Pasal 1245 bisa ditarik kesimpulan adalah bahwa peraturan-peraturan yang dikatakan diatas tidak cukup untuk bisa memberikan perlindungan hukum yang kuat dan mutlak bagi para pekerja yang terdampak pemutusan hubungan kerja pada masa pandemi COVID-19, hal ini disebabkan oleh karena bunyi KUH Perdata Pasal 1244 dan Pasal 1245 tidak terdapat bunyi yang menyatakan bahwa perusahaan dapat dimintakan pertanggungjawaban. Perusahaan harus tetap dibebankan dengan kewajibannya sesuai perjanjian untuk bisa memenuhi kewajiban kepada pekerja yang terkena pemutusan hubungan kerja, agar hak dari para pekerja yang terkena pemutusan hubungan kerja bisa diselamatkan dan dilindungi serta terotomatis kewajiban perusahaan bisa terlaksana, sebagaimana yang diatur dalam Pasal 61 Undang-Undang Nomor 1 Tahun 2003 tentang ketenagakerjaan. Dimana dalam hal ini perusahaan wajib hukumnya untuk bisa melaksanakan kewajiban secara tuntas terhadap pemenuhan hak para pekerja yang terkena dampak pemutusan hubungan kerja dengan memenuhi pembayaran upah atau gaji pekerja dan juga pesangonnya hal ini sesuai dengan bunyi ketentuan Pasal 1 Ayat 23 Undang- Undang Nomor 13 Tahun 2003.

Adapun kewajiban yang harus dipenuhi seorang pengusaha terhadap karyawan yang dipekerjakannya yang tentunya terkena pemutusan hubungan kerja untuk membayar upah /gaji diatur dalam Pasal 164 Ayat 1 Undang-Undang Nomor 13 Tahun 2003 dan telah ditegaskan juga dalam Pasal 156 Undang-Undang Nomor 13 Tahun 2003. Adapun bentuk perlindungan hukum yang diberikan pemerintah terhadap para pekerja/buruh yakni dengan membuat serta meregulasikan dan merealisasikan segala bentuk peraturan yang mengikat diantara kedua pihak yaitu pekerja dan juga suatu perusahaan, melaksanakan proses hubungan industrial, serta mengadakan pembinaanpembinaan terhadap pekerja dan perusahaan (Sutedi, 2009).

Hukum dibuat untuk bisa melindungi hak serta kewajiban setiap individu yang ada didalam suatu Negara, dengan adanya perlindungan hukum yang kuat akan menimbulkan terwujudnya tujuan hukum yakni adanya keamanan, ketentraman, Ketertiban umum, kesejahteraan, kebenaran, kedamaian dan tentunya keadilan bagi seluruh Warga Negara (Marzuki, 2008). Aturan hukum yang dikemas baik berupa undang-undang, PP, Perpres ataupun hukum yang tidak tertulis, berisi aturan-aturan yang bersifat umum namun tentunya yang menjadi pedoman hidup bangsa ataupun individu untuk mengatur pola atau cara bertingkah laku dalam hidup bermasyarakat, baik itu di hubungannya dengan sesama masyarakat ataupun makhluk lainnya. Aturan-aturan tersebut dibuat untuk bisa menjadi suatu batasan untuk masyarakat dalam melakukan suatu tindakan terhadap individu lainnya. Timbulnya suatu aturan semacam Undang-undang dan pelaksanaan aturan itu menimbulkan adanya kepastian hukum. Dengan kepastian hukum itulah mengandung adanya dua pengertian, yakni kesatu, terdapat suatu aturan yang bersifat umum yang membuat suatu individu menyadari apa perbuatan yang boleh ataupun tidak boleh untuk dilakukannya dan yang kedua, berupa kenyamanan serta keamanan hukum untuk suatu individu dari kesewenang-wenangan pemerintah daerah maupun pemerintah pusat dikarenakan adanya suatu aturan yang bersifat umum itu individu bisa untuk mengetahui apa yang dapat untuk dibebankan ataupun dilakukan suatu Negara terhadap individu atau masyarakatnya. Adapun kepastian hukum tersebut bukan semata-mata berupa pasal didalam suatu aturan tertulis atau 
disebut undang- undang, melainkan dengan adanya rasa konsisten dalam suatu putusan hakim antara putusan hakim yang satu dengan hakim lainnya yang (Marzuki, 2008).

\section{SIMPULAN DAN SARAN \\ 1. Simpulan}

Pengaturan hukum pemutusan hubungan kerja bagi pekerja pada masa pandemi COVID-19, sebagaimana diketahui merupakan suatu keadaan yang terduga (force majeure) dimana keadaan ini diatur dalam Pasal 156 Undang-undang Nomor 13 Tahun 2003 yang menyatakan bahwa suatu perusahaan dapat memberhentikan pekerjanya saat perusahaan tersebut mendapatkan kerugian secara terus menerus dan tidak mendapatkan keuntungan atau saat perusahaan akan tutup, perusahaan dalam force majeure yang memaksa untuk memberhentikan karyawan dengan tetap memenuhi kewajiban perusahaan yaitu membayar pesangon dan upah terakhir. Sebagaimana diketahui bahwa pengaturan hukum pemutusan hubungan kerja oleh perusahaan masih terdapat kewajiban perusahaan yang belum terpenuhi teruma dalam pembayaran upah atau gaji untuk pekerja. Adapun erlindungan hukum terhadap pekerja karena pemutusan hubungan kerja pada masa pandemi COVID-19 telah diatur dalam KUH Pasal 1244 KUH Perdata yang kurang lebihnya berbunyi jika orang yg berhutang tidak membayarkannya dengan suatu alasan yang tidak terduga dan tidak cakap dalam perjanjian dengan alasan yang kuat dan tidak diketahuinya. Dalam hal ini dapat dilihat bahwa perlindungan hukum bagi para pekerja belum memiliki kekuatan hukum yang mutlak dan wajib untuk direvisi.

\section{Saran}

Kepada pemerintah sebaiknya hukum yang mengatur hak-hak pekerja harus diselesaikan secara bersama-sama. Sebaiknya membuat pengaturan hukum yang baru atas hak-hak pekerja yang terkena pemutusan hubungan kerja pada masa pandemi COVID-19. Untuk masyarakat, terutama perusahaan jika kewajiban perusahaan atas gaji atau upah pekerja yang terkena pemutusan hubungan kerja belum terselesaikan, segeralah membayar upah atau gaji pekerja karena upah atau gaji tersebut sangat berharga demi kelangsungan hidup pekerja yang terkena pemutusan hubungan kerja pada masa pandemi COVID-19. Kepada masyarakat terutama yang memiliki jabatan dalam suatu perusahaan sebaiknya perlindungan hukum terhadap pekerja dibuat peraturan baru yang cukup kuat dan mampu melindungi hak-hak pekerja, karena pada saat ini pemerintah hanya menerbitkan PP Nomor 21 Tahun 2020 tentang kebijakan PSBB (Pembatasan Sosial Berskala Besar) yang merupakan strategi pemerintah untuk dapat mencegah virus corona semakin menyebar.

\section{DAFTAR PUSTAKA}

Asikin, Z. (2010). Dasar Hukum Perburuhan. Raja Grafindo Persada, Jakarta.

Hatane, K., Alfons, S. S., \& Matitaputty, M. I. (2021). Perlindungan Hukum Terhadap Pekerja di Masa Pandemi Covid-19. TATOHI, 1(3), 265-275.

Kartasapoetra, G., Kartasapoetra, R. G., \& Kartasapoetra, A. G. (1994). Hukum perburuhan di Indonesia berlandaskan Pancasila. Sinar Grafika, Jakarta.

Khakim, A. (2003). Pengantar Hukum Ketenagakerjaan Indonesia. PT. Citra Aditya Bakti, Bandung. Marzuki, P. M. (2008). Pengantar Ilmu Hukum. Kencana, Jakarta.

Ngadi, Meilianna, R., \& Purba, Y. A. (2008). Dampak Pandemi Covid-19 Terhadap PHK dan Pendapatan Pekerja di Indonesia. Jurnal Kependudukan Indonesia, 3(2), 43-48.

Pamungkas, F. A. S., \& Irawan, A. D. (2021). Perlindungan Hukum Terhadap Pekerja Akibat Pemutusan Hubungan Kerja dimasa Pandemi Covid-19. Ajudikasi Jurnal Hukum, 5(1), 99-108.

Ridwan, K. (2014). Pokok-Pokok Hukum Dagang. akultas Hukum Universitas Islam Indonesia Press. Soepomo, I. (2016). Hukum Perburuhan Indonesia Bidang Hubungan Kerja. Djambatan, Jakarta.

Sutedi, A. (2009). Hukum Perburuhan. Sinar Harapan, Jakarta.

Uwiyono, A. (2014). Asas-Asas Hukum Perburuhan. Raja Grafindo Persada, Jakarta.

Wibowoa, A. P., \& Sudiro, A. (2021). Perlindungan Hukum Terhadap Pekerja Dalam Pemutusan Hubungan Kerja (PHK) dengan Alasan Efisiensi Akibat Pandemi Covid 19. Jurnal Hukum To$R a, 7(1), 135-152$. 